\title{
Usporedba učinkovitosti i trogodišnjeg preživljenja TNF- $\alpha$ inhibitora u liječenju ankilozantnog spondilitisa
}

\section{Comparison of efficacy and three year retention rate of TNF- $\alpha$ inhibitors in treatment of ankylosing spondylitis}

\author{
Filip Mirić, Srđan Novak
}

\begin{abstract}
Sažetak. Cilj: Svrha rada bila je utvrditi i usporediti učinkovitost te preživljenje TNF- $\alpha$ (engl. tumor necrosis factor- $\alpha$ ) inhibitora (adalimumab, golimumab, infliksimab) tijekom trogodišnjeg praćenja u liječenju ankilozantnog spondilitisa. Materijali i metode: Ovim retrospektivnim istraživanjem obuhvaćena je skupina od 29 ispitanika koji su primili prvi biološki lijek na Odjelu reumatologije i kliničke imunologije Kliničkog bolničkog centra Rijeka. Započeli su s biološkim lijekom u razdoblju od siječnja 2009. do lipnja 2015. godine i bili praćeni tri godine nakon početka terapije. Parametri kojima se pratila aktivnost bolesti bili su BASDAI (engl. Bath Ankylosing Spondylitis Disease Activity Index), BASFI (engl. Bath Ankylosing Spondylitis Functional Index), CRP (engl. C reactive protein) i VAS (engl. Visual Analogue Scale), a mjereni su prije početka terapije te nakon 3 i 36 mjeseci od njenog uvođenja. Rezultati: Od ukupno 29 ispitanika, 11 ih je bilo na adalimumabu, 10 na golimumabu, a 8 na infliksimabu. Analizirajući parametre uključene u ovo istraživanje (BASDAI, BASFI, CRP, VAS), ni u jednom promatranom periodu nije zabilježena statistički značajna razlika između ispitanika s obzirom na primijenjeni TNF- $\alpha$ inhibitor (svi $p>0,05$ ). Ukupno trogodišnje preživljenje TNF- $\alpha$ inhibitora iznosilo je 75,8 \%. Kod ispitanika liječenih adalimumabom trogodišnje preživljenje iznosilo je $72,8 \%$, za golimumab $80 \%$ te infliksimab $75 \%$ (svi $p>0,05$ ). Zaključci: Uspoređujući ispitanike liječene adalimumabom, golimumabom i infliksimabom u prvoj liniji biološke terapije, naše istraživanje na malom broju ispitanika pokazalo je kako nema značajne razlike u njihovoj učinkovitosti i preživljenju.
\end{abstract}

Ključne riječi: adalimumab; ankilozantni spondilitis; golimumab; infliksimab; TNF- $\alpha$ inhibitor

Abstract. Aim: Our goal was to compare efficacy and retention rate of TNF- $\alpha$ (tumor necrosis factor- $\alpha$ ) inhibitors (adalimumab, golimumab, infliximab) during three-year follow-up in treatment of ankylosing spondylitis. Materials and methods: This retrospective study includes 29 patients who received first biological drug at Department of Rheumatology at Clinical Hospital Center Rijeka. They started with biological drug in the period from 1/2009-6/2015 and were followed for three years after the onset of therapy. Disease activity was measured with BASDAI (Bath Ankylosing Spondylitis Disease Activity Index), BASFI (Bath Ankylosing Spondylitis Functional Index), CRP (C reactive protein) and VAS (Visual Analogue Scale) on week 0, then 3 and 36 months after first therapy. Results: Among 29 patients 11 were on adalimumab, 10 on golimumab, and 8 on infliximab. By analyzing the parameters included in this study (BASDAl, BASFI, CRP, VAS) and considering the TNF- $\alpha$ inhibitor which has been used, there is no statistically significant difference in any observed period (all $p$ values $>0,05$ ). Overall 3 years retention rate for TNF- $\alpha$ inhibitors was $75,8 \%$. In patients treated with adalimumab 3 years retention rate was $72,8 \%$, for golimumab was $80 \%$ and for infliximab $75 \%$ (all p values $>0,05$ ). Conclusions: Comparing patients treated with adalimumab, golimumab and infliximab as first line of biological therapy, our study on small number of patients has shown that there is no significant difference in their efficacy and retention rate.

Key words: adalimumab; ankylosing spondylitis; golimumab; infliximab; TNF- $\alpha$ inhibitor
Klinika za internu medicinu, Klinički bolnički centar Rijeka, Rijeka

*Dopisni autor:

Filip Mirić

Klinički bolnički centar Rijeka Tome Strižića 3, 51000 Rijeka e-mail: filip.miri@gmail.com

http://hrcak.srce.hr/medicina 


\section{UVOD}

Ankilozantni spondilitis (AS) jest kronična, sistemska upalna reumatska bolest nepoznata uzroka. Zahvaća kralježnicu i velike proksimalne zglobove, a tipičan nalaz je simetrični sakroileitis uz slabo izražene znakove upalne aktivnosti. Međutim, upalni proces nerijetko može završiti koštanom metaplazijom i ankilozom. Bolest spada u grupu seronegativnih spondiloartritisa, zajedno s psorijatičnim artritisom, rekativnim artritisom, enteropatskim ar-

Ankilozantni spondilitis najčešće nastupa već u mlađoj dobi (između 20 i 40 godina), tri puta je češći u muškaraca, a bez rane dijagnoze i pravodobnoga liječenja povezan je sa znatnim simptomatskim tegobama i smanjenjem funkcionalne sposobnosti u najproduktivnijim godinama života.

tritisom te nediferenciranim spondiloartritisom ${ }^{1,2}$. Postoji značajna povezanost pojavnosti ankilozantnog spondilitisa i HLA-B27 (engl. human leukocyte antigen-B27) antigena. Tako osobe s pozitivnim HLA-B27 antigenom imaju 1 - 2 \%-tni rizik razvoja bolesti, dok krvni srodnik pacijenta pozitivnog na HLA-B27 ima $20 \%$-tni rizik obolijevanja ${ }^{3}$. Zahvaćeni zglob infiltriran je s CD4+ i CD8+ T limfocitima i makrofagima te pokazuje visoke razine TNF- $\alpha$ (engl. tumor necrosis factor- $\alpha$ ) i TGF- $\beta$ (engl. transforming growth factor- $\beta$ ), za koje se pretpostavlja da su, uz interleukin 17, ključni efektorski citokini zaslužni za destrukciju hrskavice i stvaranje nove kosti ${ }^{4}$. U današnje vrijeme učinjeni su znatni pomaci u liječenju ove bolesti gdje glavnu ulogu zauzimaju biološki lijekovi, prvenstveno TNF- $\alpha$ inhibitori ${ }^{5}$. Trenutno ih je dostupno pet, od kojih su četiri monoklonska protutijela: adalimumab, golimumab, infliksimab i certolizumab pegol, a jedan je solubilni receptor - antagonist TNF- $\alpha$, etanercept. Osim TNF- $\alpha$ inhibitora $u$ biološkoj terapiji ankilozantnog spondilitisa primjenjuje se i inhibitor interleukina 17 , sekukinumab ${ }^{6}$. Danas svoje mjesto u biološkoj terapiji sve češće zauzimaju i bioslični lijekovi. To su kopije referentnih, originalnih bioloških lijekova kojima je istekla licencija, pa su zbog toga i jeftiniji od njih $^{6,7}$. Trenutno na tržištu postoje bioslični inflik- simab i etanercept, a recentno su odobreni i bioslični adalimumabi ${ }^{8,9,10}$.

$\mathrm{U}$ radu je analizirana djelotvornost originalnih bioloških lijekova - adalimumaba, golimumaba i infliksimaba, budući da se oni najduže primjenjuju, dok etanercept i certolizumab pegol nisu uzeti u obzir, s obzirom na premali uzorak, kao ni certolizumab pegol, zbog prekratkog prisustva na tržištu potrebnog za ovo istraživanje. Adalimumab i golimumab potpuno su humana monoklonska protutijela IgG1k čija se djelovanja očituju blokadom i solubilnog i transmembranskog TNF- $\alpha$ te prekidom daljnjih učinaka TNF- $\alpha$ u proupalnoj kaskadi. Adalimumab se primjenjuje supkutano $u$ dozi od 40 mg svaki drugi tjedan, a golimumab jednom mjesečno u dozi od 50 mg ${ }^{11,12}$. Infliksimab je kimerično humano-mišje monoklonsko protutijelo IgG1k, a također blokira solubilni i transmembranski TNF- $\alpha$. Primjenjuje se u dozi od $5 \mathrm{mg} / \mathrm{kg}$ intravenskom infuzijom, a zatim slijede dodatne infuzije u dozi od $5 \mathrm{mg} / \mathrm{kg} 2$. i 6 . tjedna nakon prve infuzije te svakih 8 tjedana nakon toga ${ }^{13}$.

\section{ISPITANICI I METODE}

Retrospektivnim istraživanjem obuhvaćena je skupina od 29 ispitanika koji su započeli s biološkom terapijom u razdoblju od siječnja 2009. do lipnja 2015. godine. Istraživanje je provedeno prikupljanjem podataka iz medicinske dokumentacije Odjela za reumatologiju i kliničku imunologiju na Klinici za internu medicinu Kliničkog bolničkog centra Rijeka, a razdoblje za koje su podaci prikupljeni je od siječnja 2009. do lipnja 2018. godine. Svaki pacijent praćen je ukupno tri godine od započinjanja s terapijom, a uvjet je bio da mu je to prvi biološki lijek koji je primio. Ispitanici su podijeljeni u tri skupine, a prvu skupine čine pacijenti na biološkoj terapiji adalimumabom te su navedeni kao skupina „A“. U drugoj skupini su pacijenti na biološkoj terapiji golimumabom (navedeni kao skupina „G“), dok treću skupinu čine pacijenti liječeni infliksimabom (navedeni kao skupina „I"). U istraživanju su korištene validirane hrvatske verzije upitnika BASDAI (engl. Bath Ankylosing Spondylitis Disease Activity Index) i BASFI (engl. Bath Ankylosing Spondylitis Functional Index) te su u svim skupinama određivani njihovi indeksi, zatim laboratorijski marker upale CRP 
(engl. C reactive protein) te procjena bola VAS ljestvicom (engl. Visual Analogue Scale) ${ }^{14}$. Praćeni su u trenutku započinjanja s terapijom, te nakon 3 i 36 mjeseci. Osim usporedbe između skupina, analiziran je i svaki lijek zasebno u mjerenim vremenima s obzirom na promatrane parametre. Napravljena je analiza ukupnog trogodišnjeg preživljenja TNF- $\alpha$ inhibitora te međusobna usporedba između triju skupina. Također je analizirano preživljenje bioloških lijekova s obzirom na njihovu komedikaciju s lijekovima koji modificiraju upalni tijek bolesti, odnosno DMARD-ovima (engl. Disease Modifying AntiReumatic Drugs).

\section{Statistička obrada podataka}

Statistička obrada podataka napravljena je u računalnom programu Statistica, verzija 12 (Dell Inc. 2015). Kolmogorov-Smirnovljevim testom utvrđena je normalnost raspodjele podataka. Normalno raspodijeljene kontinuirane numeričke varijable opisane su i prikazane grafički uz medijan i interkvartilna raspršenja, a kategoričke (nebrojčane) varijable, kao što je spol ispitanika, opisane su frekvencijom, odnosno postotnim udjelom. Usporedbe vrijednosti numeričkih varijabli (BASDAI, BASFI, CRP, VAS) učinjene su neparametrijskim Kruskall-Wallisovim testom, čime se određivalo postoji li statistički značajna razlika između triju skupina TNF- $\alpha$ inhibitora. Trogodišnje preživljenje TNF- $\alpha$ inhibitora analizirano je Kaplar-Meierovom metodom, a usporedba između skupina Log-rank testom. Kao razina statističke značajnosti zaključivanja u svim analizama primjenjivan je $p<0,05$.

\section{REZULTATI}

Životna dob svih ispitanika normalno je raspodijeljena ( $p>0,20$; slika 1). Najmlađa osoba ima 30 go- dina, a najstarija je u dobi od 70 godina. S obzirom na primijenjeni lijek nije utvrđena značajna razlika u dobi ( $p>0,05$; tablica 1$)$ i spolu ispitanika među skupinama A, G i I, međutim, utvrđeno je kako je u sve tri skupine značajno više muškaraca ( $p<$ $0,05)$. Uspoređujući vrijednosti BASDAI-ja nije utvrđena statistički značajna razlika u vremenima praćenja između skupina A, G i I (svi $p>0,05$; slike $2-4$ ), a isto vrijedi i za BASFI (svi $p>0,05$; slike 5 - 7). Također, nigdje nije zabilježena statistička značajna razlika u vrijednostima CRP-a i VAS vrijednosti u vremenima praćenja među ispitanicima u skupinama A, G i I (svi $p>0,05$; slike 8-13). Kod svakog od ispitivanih lijekova zabilježena je statistički značajna razlika nakon tri mjeseca u odnosu na početak terapije za svaki od promatranih parametara (svi $p<0,05$ ). Ukupno trogodišnje preživljenje TNF- $\alpha$ inhibitora iznosi 75,8 \% (slika 14), dok za adalimumab ono iznosi $72,8 \%$, za golimumab $80 \%$ te infliksimab $75 \%$ (slika 15). Nije

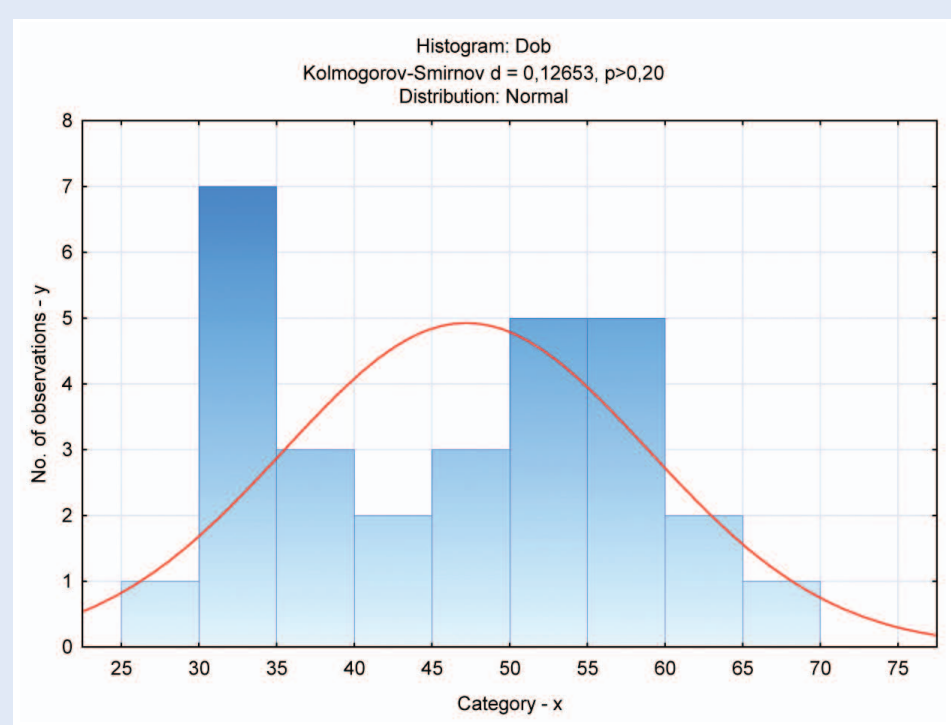

Slika 1. Raspodjela svih ispitanika prema životnoj dobi

Tablica 1. Srednja dob ispitanika

\begin{tabular}{|c|c|c|c|c|}
\hline \multirow{2}{*}{ Skupina } & \multirow{2}{*}{$n$} & \multicolumn{2}{|c|}{ Dob/godine } & \multirow{2}{*}{ Statistika } \\
\hline & & $\pm S D$ & Raspon & \\
\hline$A$ & 11 & $49,2 \pm 10,42$ & $35-70$ & \multirow{3}{*}{$p=0,672$} \\
\hline G & 10 & $44,6 \pm 12,28$ & $30-62$ & \\
\hline 1 & 8 & $47,6 \pm 13,64$ & $31-65$ & \\
\hline Ukupno & 29 & $47,2 \pm 11,74$ & $30-70$ & \\
\hline
\end{tabular}

$\mathrm{A}=$ adalimumab; $\mathrm{G}$ = golimumab; I = infliksimab; SD = standardna devijacija 


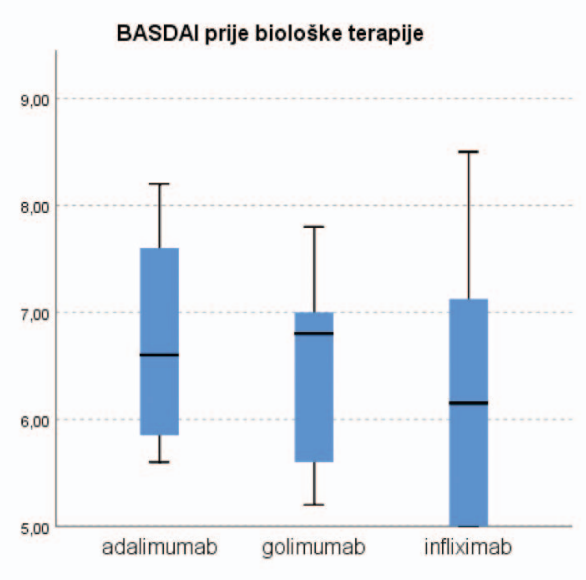

$p=0,562$

Slika 2. Medijan i interkvartilno raspršenje vrijednosti BASDAI-ja prije početka uzimanja biološke terapije

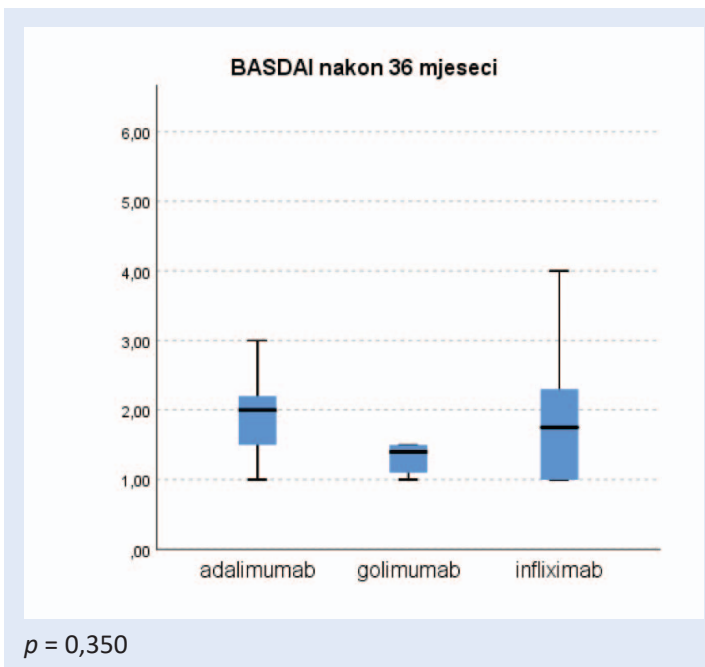

Slika 4. Medijan i interkvartilno raspršenje vrijednosti BASDAI-ja nakon 36 mjeseci

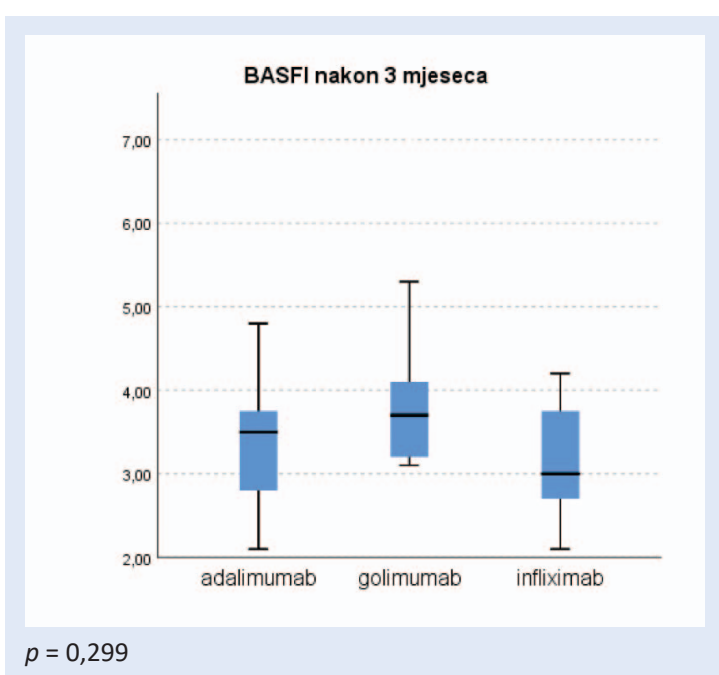

Slika 6. Medijan i interkvartilno raspršenje vrijednosti BASFI-ja nakon 3 mjeseca

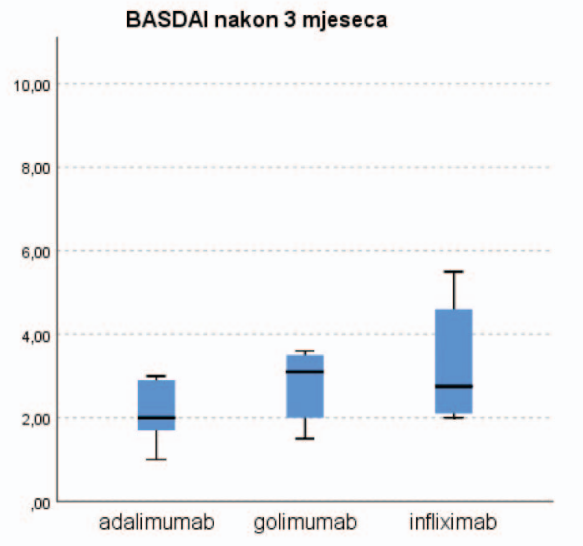

$p=0,223$

Slika 3. Medijan i interkvartilno raspršenje vrijednosti BASDAI-ja nakon 3 mjeseca

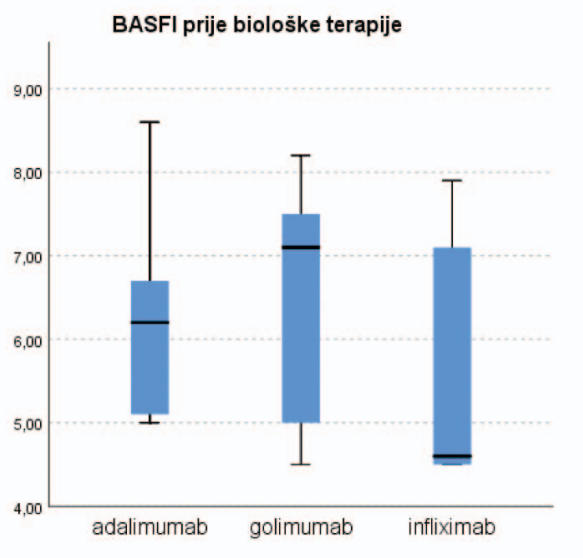

$p=0,251$

Slika 5. Medijan i interkvartilno raspršenje vrijednosti BASFI-ja prije početka uzimanja biološke terapije

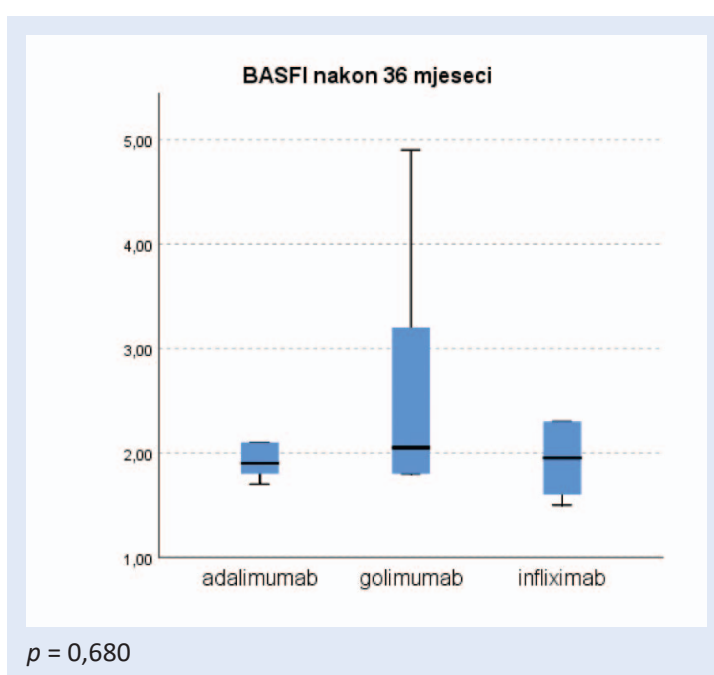

Slika 7. Medijan i interkvartilno raspršenje vrijednosti BASFI-ja nakon 36 mjeseci 


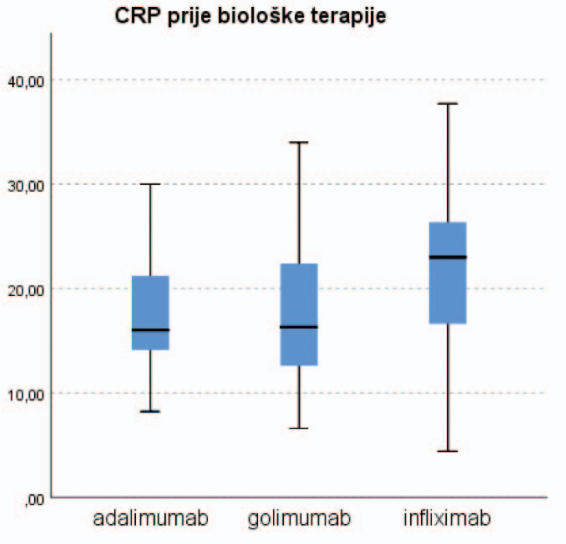

$p=0,392$

Slika 8. Medijan i interkvartilno raspršenje vrijednosti CRP-a prije početka uzimanja biološke terapije

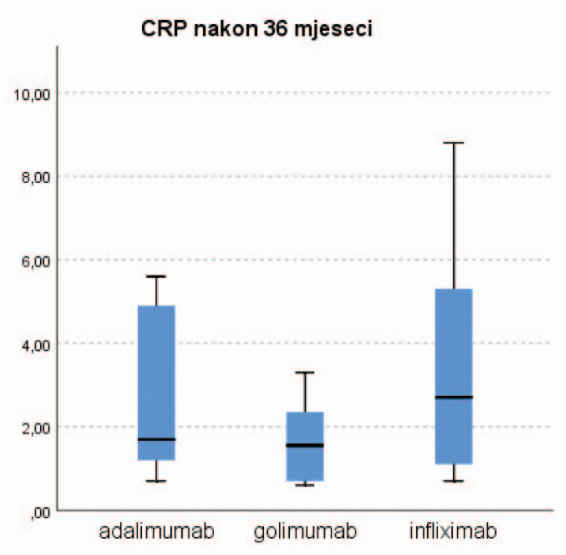

$p=0,339$

Slika 10. Medijan i interkvartilno raspršenje vrijednosti CRP-a nakon 36 mjeseci

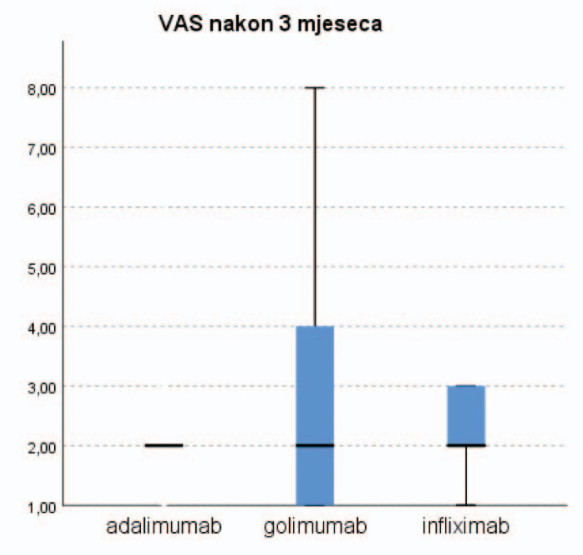

$p=0,833$

Slika 12. Medijan i interkvartilno raspršenje vrijednosti VAS-a nakon 3 mjeseca

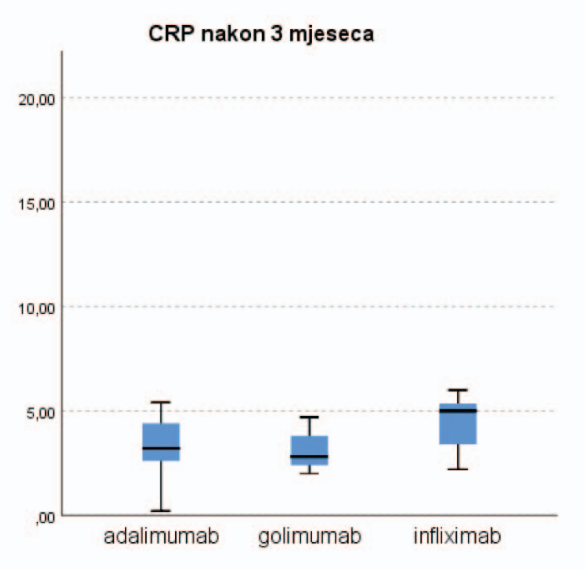

$p=0,211$

Slika 9. Medijan i interkvartilno raspršenje vrijednosti CRP-a nakon 3 mjeseca

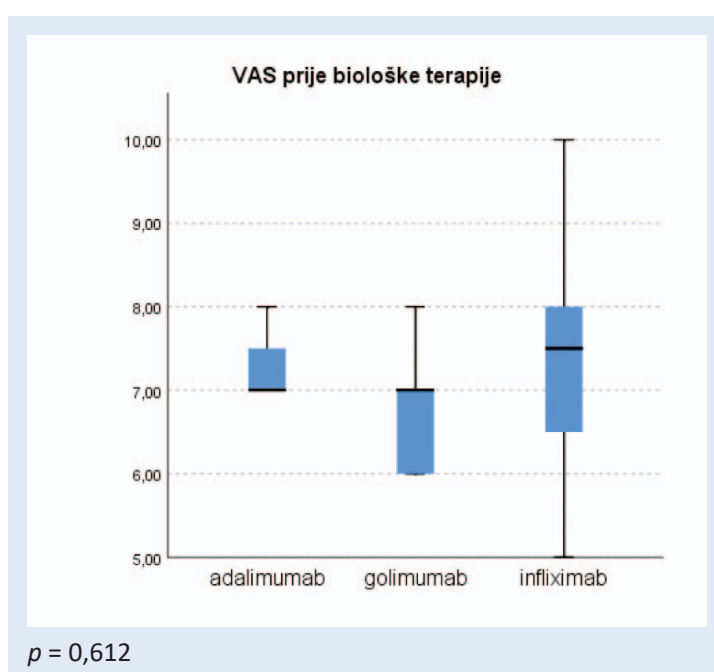

Slika 11. Medijan i interkvartilno raspršenje vrijednosti VAS-a prije početka uzimanja biološke terapije

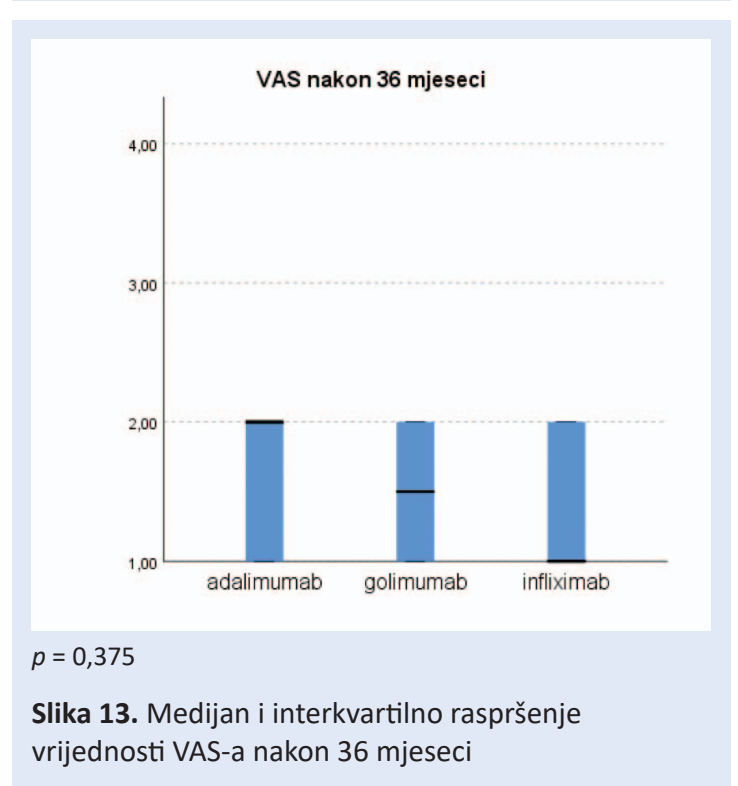




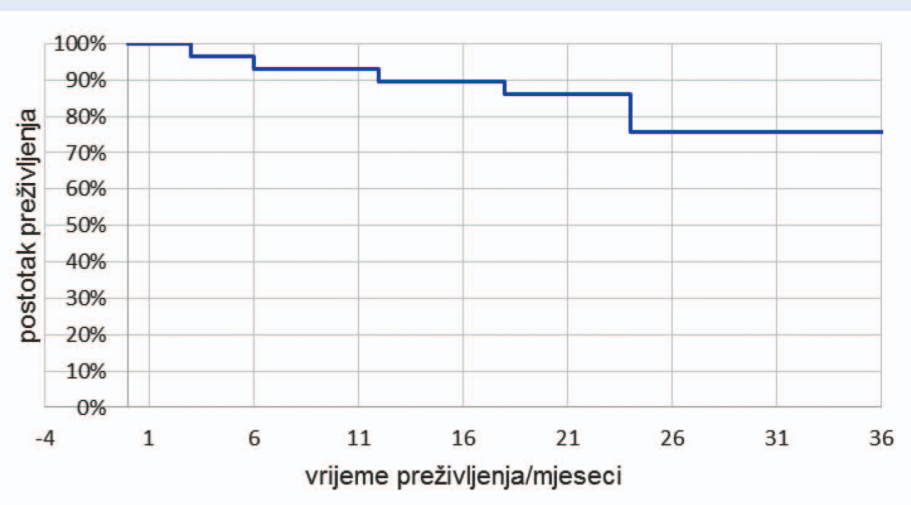

Slika 14. Ukupno trogodišnje preživljenje TNF- $\alpha$ inhibitora

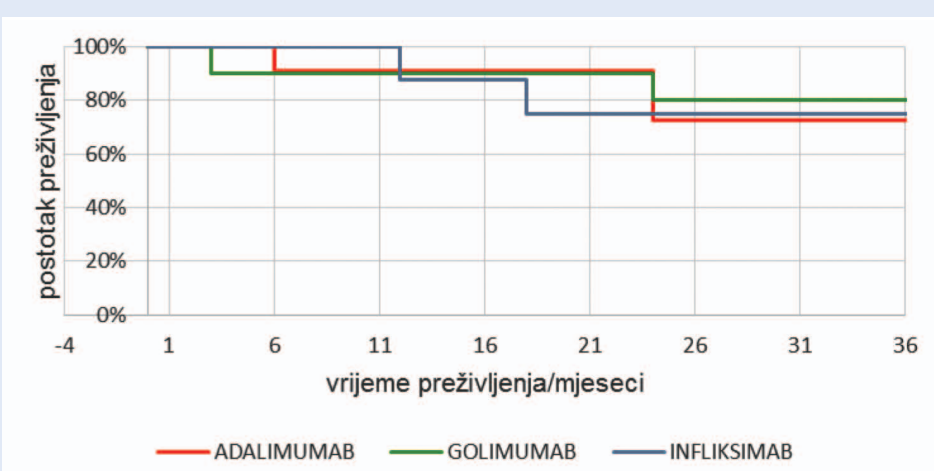

Slika 15. Usporedba trogodišnjeg preživljenja adalimumaba, golimumaba i infliksimaba

zabilježena statistički značajna razlika uspoređujući preživljenje adalimumaba i golimumaba $(p=$ $0,752)$, te adalimumaba i infliksimaba $(p=0,980)$, kao niti između golimumamba i infliksimaba ( $p=$ $0,802)$. Analizom preživljenja bioloških lijekova uz njihovu komedikaciju s DMARD-om zabilježen je pozitivan trend preživljenja kod navedene komedikacije (slika 16).

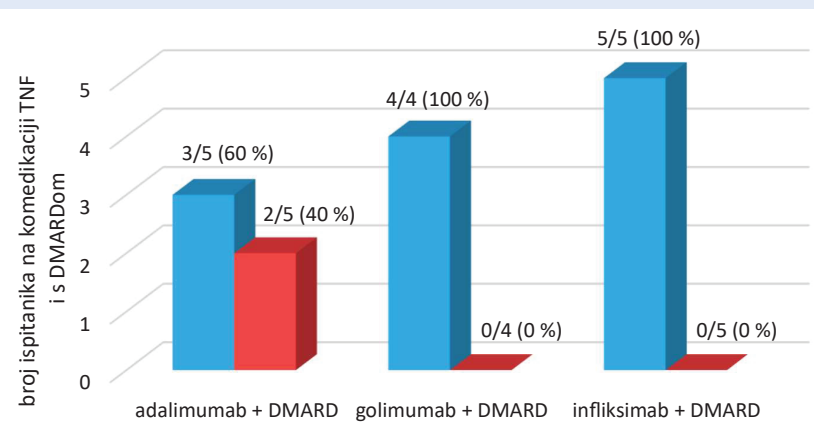

— "preživljenje" TNF- $\alpha$ inhibitora — "ukidanje" TNF- $\alpha$ inhibitora

$(n=14)$

Slika 16. Prikaz „preživljenja/ukidanja“ TNF- $\alpha$ inhibitora s obzirom na komedikaciju s DMARD-om

\section{RASPRAVA}

Cilj rada bio je usporediti učinkovitost i trogodišnje preživljenje TNF- $\alpha$ inhibitora u liječenju ankilozantnog spondilitisa. Svi ispitanici u istraživanju zadovoljili su kriterije Hrvatskog zavoda za zdravstveno osiguranje (HZZO) koji se tiču uvođenja biološke terapije u liječenju AS-a (dijagnoza AS po Modificiranim njujorškim kriterijima ili ASAS-ovim kriterijima (engl. Assessment of SpondyloArthritis International Society); BASDAI $\geq 4,0$ ili ASDAS $\geq 2,1$ (engl. Ankylosing Spondylitis Disease Activity Score); izostanak učinka ili nepodnošljivost za najmanje dva nesteroidna antireumatika koji su primjenjivani u punoj dozi tijekom najmanje 4 tjedna te težina bolesti iznad 4 prema procjeni reumatologa). Napominjemo kako je svima to ujedno bio i prvi biološki lijek ${ }^{4,15}$. Iz podataka dobivenih ovim istraživanjem vidljivo je kako je udio muškaraca daleko veći u odnosu na udio žena (23:6), što je u skladu s epidemiološkom slikom ove bolesti ${ }^{1}$. BASDAI je jedan od osnovnih pokazatelja ocjene aktivnosti bolesti ${ }^{16}$. Vidljivo je kako se unutar svake grupe zasebno vrijednost BASDAI-ja s vremenom snižava, što je i u skladu s pozitivnim učinkom biološke terapije, kako se pokazalo i u brojnim dosadašnjim istraživanjima ${ }^{11,13,17}$.

BASFI kao drugi korišteni indeks govori u prilog funkcionalnoj aktivnosti bolesti ${ }^{16}$. Ovdje, kao i u slučaju BASDAI-ja, vrijednosti se vremenom smanjuju u sve tri skupine, te u ovom istraživanju nije utvrđena statistički značajna razlika s obzirom na primijenjeni TNF- $\alpha$ inhibitor (slike $5-7$ ). U velikoj studiji Maxwella, Zochlinga i sur. iz 2015. godine također je pokazano kako BASFI ne pokazuje značajna odstupanja ovisno o tipu navedenih TNF- $\alpha$ inhibitora 5 .

Unutar promatranog perioda od 36 mjeseci redovito je praćen i CRP kao najčešće korišteni laboratorijski marker upale. S obzirom na izraženost upalne komponente bolesti, vrijednosti CRP-a prije početka biološke terapije bile su povišene, ali već nakon 3 mjeseca snižavaju se unutar svake skupine ispitanika (slike $8-10$ ). Ni u jednom od vremena praćenja nije zabilježena statistički značajna razlika između navedenih skupina TNF- $\alpha$ inhibitora, stoga ni razina CRP-a ne odstupa ovisno o upotrijebljenom biološkom lijeku, što je pokazalo i Gossenovo istraživanje ${ }^{18}$. 
Kod srednjih vrijednosti procjene bola na VAS ljestvici također nije zabilježena statistički značajna razlika ni u jednom od mjerenja (slike 11 - 13), što govori o podjednakom učinku različitih TNF- $\alpha$ inhibitora na doživljaj bola ispitanika, kako je pokazalo i istraživanje talijanskih znanstvenika ${ }^{19}$. Uspoređujući parametre u mjerenim vremenima za svaku skupinu zasebno, zabilježena je statistički značajna razlika kod svakog lijeka nakon tri mjeseca u odnosu na početak terapije za svaki od promatranih parametara, a nakon toga se vrijednosti značajno ne razlikuju. Taj podatak govori u prilog brzom učinku adalimumaba, golimumaba i infliksimaba, što se pokazalo i u više dosadašnjih istraživanja ${ }^{20,21}$.

Ukupno trogodišnje preživljenje TNF- $\alpha$ inhibitora iznosi 75,8 \% (slika 14), što korelira s nekim dosadašnjim istraživanjima, poput onog korejskih te danskih znanstvenika ${ }^{22,23}$. Usporedba trogodišnjeg preživljenja svake skupine TNF- $\alpha$ inhibitora međusobno utvrdila je kako adalimumab, golimumab i infliksimab imaju približno jednako trogodišnje preživljenje (slika 15). Rezultati Fabronnija i suradnika također govore u prilog podjednakom preživljenju različitih skupina TNF- $\alpha$ inhibitora ${ }^{24}$.

Pacijenti s perifernim artritisom koji se javlja u sklopu spondiloartritisa uzimaju DMARD kao dio terapije. Dosadašnja istraživanja pokazuju oprečna stajališta o preživljenju biološkog lijeka u komedikaciji s DMARD-om ${ }^{25,26}$. U ovome istraživanju 14 pacijenata uzimalo je DMARD, a primjenjivani su bili metotreksat i sulfasalazin. Svi ispitanici na komedikaciji DMARD-a s golimumabom te infliksimabom ostali su na početnoj biološkoj terapiji, dok je trogodišnje preživljenje na komedikaciji DMARD-a s adalimumabom iznosilo $60 \%$ (slika 16). Vidljiv je prisutni pozitivni trend preživljenja biološkog lijeka u sve tri skupine, kao što je pokazalo i istraživanje Liea i Kristesena iz 2015. godi$n e^{26}$.

Retrospektivno praćenje i relativno malen broj ispitanika, kao i činjenica da su analizirana tri od postojećih pet TNF- $\alpha$ inhibitora, predstavljaju ograničenja ovoga rada.

\section{ZAKLJUČCI}

Naše istraživanje pokazalo je da se adalimumab, golimumab i infliksimab međusobno značajno ne razlikuju u svojoj djelotvornosti, jer su svi parametri koje smo uključili $u$ istraživanje (BASDAI, BASFI, CRP, VAS) pokazivali slične vrijednosti. Osim toga, kod svakog od navedenih lijekova pokazano je kako postiže brzu učinkovitost. Također je zaključeno kako nije prisutna razlika u njihovom trogodišnjem preživljenju s obzirom na primijenjeni TNF- $\alpha$ inhibitor.

Naposljetku, istraživanje je pokazalo kako je terapija DMARD-ovima imala pozitivan učinak na preživljenje svakog od bioloških lijekova.

Nakon što su ispitanici praćeni tri godine od uvođenja biološkog lijeka, utvrđeno je kako se vrijednosti promatranih parametara (BASDAI, BASFI, CRP i VAS) značajno ne razlikuju $s$ obzirom na primijenjeni TNF- $\alpha$ inhibitor (adalimumab, golimumab, infliksimab).

S obzirom na broj ispitanika, teško je donositi značajnije zaključke, no i ovaj mali uzorak potvrđuje tezu kako su različiti TNF- $\alpha$ inhibitori podjednako učinkoviti i sigurni u liječenju ankilozantnog spondilitisa.

Izjava o sukobu interesa: Autori izjavljuju da ne postoji sukob interesa.

\section{LITERATURA}

1. Anić B, Babić Naglić Đ. Seronegativni spondiloartritisi. In: Vrhovac B, Jakšić B, Reiner Ž, Vucelić B (eds). Interna medicina. Zagreb: Medicinska biblioteka, 2008;1380-2.

2. Grazio S. Klasifikacija i dijagnoza aksijalnih spondiloartritisa - povijest, sadašnje stanje i perspektive. Reumatizam 2016;63:1-17.

3. Glasnović M. Epidemiologija spondiloartritisa. Reumatizam 2011;58:24-35.

4. Taurog JD. The Spondyloarthritides. In: Fauci SA. Harrison's Rheumatology, 3rd Edition, 2013;135-40. Available from: http://medicina-ucr.com/quinto/wp-content/ uploads/2015/02/Harrisons-Rheumatology-3ED-2013. pdf.

5. Maxwell LJ, Zochling J, Boonen A, Singh JA, Veras MMS, Tanjong $E$ et al. TNF-alpha inhibitors for ankylosing spondylitis. Cochrane Database Syst Rev 2015;4:54-68.

6. Grazio $S$, Novak S, Laktašić Žerjavić N, Anić B, Babić Naglić $Đ$, Grubišić $F$ et al. Prijedlog preporuka Hrvatskoga reumatološkog društva za liječenje odraslih bolesnika $\mathrm{s}$ aksijalnim spondiloartritisom i psorijatičnim artritisom biološkim lijekovima i ciljanim sintetskim molekulama, 2017. Reumatizam 2017;64:71-87.

7. Jha A, Upton A, Dunlop WC, Akehurst R. The budget impact of biosimilar infliximab (Remsima) for the treatment of autoimmune diseases in five european countries. Adv Ther 2015;32:742-56. 
8. Azevedo VF, Galli N, Kleinfelder A, D'Ippolito J, Urbano P. Etanercept biosimilars. Rheumatol Int 2014;35:80-5.

9. Fiorino G, Gilardi D, Correale C, Furfaro F, Roda G, Loy L et al. Biosimilars of adalimumab: the upcoming challenge in IBD. Expert Opin Biol Ther 2019;10:122-8.

10. Heo A. GP2017: An adalimumab biosimilar. BioDrugs 2018;32:635-8.

11. Mounach A, Maghraoui A. Efficacy and safety of adalimumab in ankylosing spondylitis. Open Access Rheumatol 2014;6:83-90.

12. Anić $B, B a b i c ́$ Naglić $Đ$, Grazio $S$, Kehler T, Martinović Kaliterna $\mathrm{D}$, Maštrović Radončić $\mathrm{K}$ et al. Retrospektivna analiza podataka bolesnika oboljelih od upalnih reumatskih bolesti u Hrvatskoj liječenih golimumabom. Reumatizam 2015;62:12-9.

13. Grainger R, Harrison A. Infliximab in the treatment of ankylosing spondylitis. Biologics 2007;12:163-71.

14. Grazio S, Grubišić F, Nemčić T, Matijević V, Skala H. Pouzdanost i valjanost hrvatske inačice bath funkcijskog indeksa za ankilozantni spondilitis (BASFI) i bath indeksa aktivnosti bolesti za ankilozantni spondilitis (BASDAI) u pacijenata $s$ ankilozantnim spondilitisom. Reumatizam 2009;56:63-76.

15. Heijde D, Ramiro S, Landewe R, Baraliakos X, Van den Bosch F, Sepriano A et al. 2016 update of the ASAS-EULAR management recommendations for axial spondyloarthritis. Ann Rheum Dis 2017;76:978-91.

16. Bobek D, Žagar I, Kovač Dumiš K, Perić P, Ćurković B, Babić Naglić $\bigoplus$. Ocjena aktivnosti ankilozantnog spondilitisa primjenom BASDAI i ASDAS instrumenta. Reumatizam 2011;58:138

17. Wang $\mathrm{Y}$, Wang $\mathrm{H}$, Jiang J, Zhao $\mathrm{D}$, Liu Y. Comparative efficacy and acceptability of anti TNF-alpha therapy in ankylosing spondylitis: A mixed treatments comparison. Cell Physiol Biochem 2016;39:1679-94.

18. Gossen N, Kostev K. Reduction in C-reactive protein with biologic drugs in rheumatoid arthritis and spondylitis pa- tients in German rheumatologist practices. Value Health 2015;18:635-42.

19. Lorenzin M, Ortolan A, Franollardo P, Oliveiro F, Punzi L, Ramonda R. Predictors of response and drug survival in ankylosing spondylitis patients treated with infliximab. BMC Musculoskelet Disord 2015;16:166-71.

20. Lambert R, Salonen $D$, Rahman $P$, Inman R, Wong R, Einstein $S$ et al. Adalimumab significantly reduces both spinal and sacroiliac joint inflammation in patients with ankylosing spondylitis. Arthritis Rheum 2007;56:4005-14.

21. Inman R, Davis J, Heijde D, Diekman L, Sieper J, Kim S et al. Efficacy and safety of golimumab in patients with ankylosing spondylit is. Arthritis Rheum 2008;58:3402-12.

22. Park EH., Oh S, Kim HA, Park YB, Shin K. Comparison of retention rates between tumour necrosis factor-alpha inhibitors in ankylosing spondylitis patients: Data from the Korean College of rheumatology biologics registry. Ann Rheum Dis 2018;77:1003-4.

23. Glintborg B, Ostergaard M, Steen Krogh N, Dreyer L, Lene Kristensen H, Lund Hetland M. Predictors of treatment response and drug continuation in 842 patients with ankylosing spondylitis treated with anti-tumour necrosis factor: results from 8 years surveillance in the Danish nationwide DANBIO registry. Ann Rheum Dis 2010;69:724-36.

24. Fabbroni M, Cantarini L, Caso F, Costa L, Pagano VA, Frediani $B$ et al. Drug retention rates and treatment discontinuation among anti-TNF- $\alpha$ agents in psoriatic arthritis and ankylosing spondylitis in clinical practice. Mediators Inflamm 2014;14:862-9.

25. Chen J. Lin S. Sulfasalazine for ankylosing spondylitis. Cochrane Database Syst Rev 2014;11:41-60.

26. Lie E, Kristensen LE, Forsblad H, Zverkova T, Askling J, Jacobsson JT et al. The effect of comedication with conventional synthetic disease modifying antirheumatic drugs on TNF inhibitor drug survival in patients with ankylosing spondylitis and undifferentiated spondyloarthritis: results from a nationwide prospective study. Ann Rheum Dis 2015; 74:970-8. 